\title{
Exploring Differences in Work's Meaning: An Investigation of Individual Attributes Associated with Work Orientations
}

\author{
Rita J. Shea-Van Fossen \\ Ramapo College of New Jersey \\ Donald J. Vredenburgh \\ Baruch College, The City University of New York
}

Author's Notes

Rita J. Shea-Van Fossen, Anisfield School of Business, Ramapo College of New Jersey; Donald J. Vredenburgh, Zicklin School of Business, Baruch College, The City University of New York.

An earlier version of this paper was presented at the 2011 Academy of Management Annual Conference, San Antonio, TX, August 2011.

Correspondence concerning this article should be addressed to Rita J. Shea-Van Fossen, Anisfield School of Business, Ramapo College of New Jersey, 505 Ramapo Valley Road, Mahwah, NJ 07430. E-mail: rshea@ramapo.edu

\begin{abstract}
To understand better the meanings of work for individuals, we explored work orientation and examined empirically individual attributes of proactive personality, concern for others, concern for self, preference for challenging work, and work enjoyment as related to job, career and calling work orientations. Age, income, and employment security were identified as control variables. Our data derived from an online survey of full-time blue-collar and corporate employees in the auto industry $(n=251)$. Our study findings suggest preference for challenging work differentiates job, career, and calling orientations. We discuss the implications of our findings and suggest areas for future research.
\end{abstract}

Keywords: work meaning, work orientation

\section{Introduction}

Historically, work has been accorded diverse meanings. The ancient Greeks attributed work to a curse that separated a person from leisure and a good life (Grant, 1960), while Max Weber's (1958) description of the Protestant ethic attributed work to a noble cause. Work plays a significant role in most individuals' lives, but the psychological meaning of work varies across individuals. Studies have substantiated that individuals who attributed meaning to their paid employment as more than just a source of financial rewards experienced greater job satisfaction (Mottaz, 1985), higher psychological well-being (Claes \& Ruiz Quintanilla, 1994), decreased turnover intentions (George \& Jones, 1996) and fewer self-reported sick days (Wrzesniewski, McCauley, Rozin \& Schwartz, 1997). Because of the implications of work meaning for 
individual and organizational outcomes, researchers (Dik \& Duffy 2009; Hall \& Chandler, 2005) have called for more studies investigating meaning within the work environment.

\section{Work Meaning}

The concept of the meaning of work refers to an individual's beliefs, values, and attitudes about the outcomes of work and the functions or purposes that work serves in life (Brief \& Nord, 1990; Chalofsky, 2003). The conceptualization of work meaning has taken many forms, resulting in a fragmented literature (for a comprehensive review, see Brief and Nord, 1990). Roberson (1990), in an attempt to clarify these various conceptualizations, identified three categories of work meaning: work centrality, work values, and work orientation. Work centrality addresses the priority of work relative to other life interests (Dubin, 1956). Work values consist of relatively enduring ideals for work behaviors and outcomes (Dawis, 1991; England, 1967). Work orientation addresses the purposes work serves in an individual's life for the experience of meaning. This study focuses on better understanding individual work orientation. Specifically, our objective is to advance knowledge of the work orientation construct by examining empirically the individual attributes associated with an individual's work orientation, thereby clarifying the concept's utility for understanding the meaning of work.

\section{Work Orientation}

The concept of work orientation captures variations in the subjective meanings attached to work (Bellah, Madsen, Sullivan, Swidler \& Tipton, 1985). Sociological research (Bellah et al., 1985) and psychological research (Wrzesniewski et al., 1997) have suggested three distinct orientations to define the various meanings of work: job, career, and calling. Individuals with primarily a job orientation view work as an instrumental activity providing the financial resources for other life activities. For them, work is mostly a means for making money. Individuals with primarily a career orientation view work as a source of self-esteem through achievement and advancement in an occupation. For them, work is a means to obtain personal success and recognition. Finally, individuals with primarily a calling orientation view work as a purposeful end unto itself, as opposed to emphasizing extrinsic rewards. For them, work provides meaning (Steger, Frazier, Oishi, \& Kaiser, 2006) and personal mission (Elangoven, Pinder \& McLean, 2010). While Wrzesniewski et al. (1997) provided empirical support for Bellah et al.'s (1985) tripartite model of work orientations, they acknowledged the need for greater clarity about conceptual distinctions among the three orientations. The tripartite model of work orientation assumes that individuals can derive job, career, or calling meanings from diverse types of work because one's work orientation comes from individual attributes interacting with work characteristics (Wrzesniewski, 2003).

Bloch (1997), in a review of career development theories (Holland, 1992; Super, 1980), noted that these theories did not address the question of work meaning. In addition, other researchers (Dekas \& Tosti, 2008) have observed the need for more precise conceptualization and operationalization of work's purposes. Due to the potential utility of the work orientation concept for individuals and organizations, the present study seeks to expand our knowledge of work meaning by clarifying the work orientation concept and exploring the individual attributes distinguishing job, career, and calling work orientations. 


\section{Clarification of the Work Orientation Concept}

We define work orientation as the fundamental purposes paid work serves in the context of one's life and a reflection of how individuals find meaning in the work domain. This definition of work orientation differs from prior definitions in two important ways: defining work orientation in terms of purpose for work instead of relationship with work and defining work orientation as a value instead of an attitude. Roberson (1990), Wrzesniewski (1999), and Dekas and Kamin (2008) defined work orientation as a person's general relationship to work, but understanding work orientation more specifically in terms of purposes and psychological meaning allows the developed theorizing suggested by Roberson (1990). Wrzesniewski (1999) categorized work orientation as an attitude, yet she and Dobrow (2006) described work orientation as a relatively stable disposition, undergoing only gradual changes over a person's work life and not changing from task to task or job to job, thus suggesting that work orientation is primarily value based. Understanding work orientation as a value, developed through socialization experiences over time, is consistent with the other work meaning categories identified by Roberson (1990).

\section{Dimensionality of Work Orientation}

Assessments of the work orientation construct's dimensionality have proven inconsistent. Bellah et al. (1985) created a tripartite model of work orientation delineating job, career, and calling categories. Although subsequent studies affirmed the existence of these three orientations (Davidson \& Caddell, 1994; Wrzesniewski et al., 1997), Wrzesniewski (1999) conceptualized job and calling orientations as ends on a single dimension, with career orientation being orthogonal to them.

Earlier studies of work orientation (Davidson \& Caddell, 1994; Wrzesniewski, 1999; Yugo, 2006) assumed an individual had a single work orientation. However, Cardador (2008) found police officers who identified primarily with career orientation also expressed job and calling orientations, suggesting individuals can attribute multiple purposes simultaneously to work's function in their lives. Wrzesniewski et al. (1997) also noted simultaneous work orientations, and they recognized the possibility of individuals having profiles containing more than one work orientation. The likelihood of a person having simultaneous work orientations is also consistent with work values studies (Cable \& Edwards, 2004; Schwartz, 1994). Schwartz (1994) found that individuals order values in importance relative to other values to form a system of value priorities. Work orientation may share this value characteristic, such that individuals order a given work orientation in importance relative to the other work orientations to form a system of prioritized orientations. Thus while the three work orientations are conceptually independent, representing distinguishable life purposes for work, they may form a system of individually prioritized work orientations (Cardador, 2008; Tosti, 2008; Yugo, 2006). Clearly, the research on work orientation is in a nascent state (Dekas \& Tosti, 2008) and deserves additional theoretical and empirical development.

\section{Individual Attributes and Work Orientations}

Previous research considered the applicability of the job, career, and calling typology across diverse occupations (Davidson \& Caddell, 1994; Wrzesniewski, 2003; Wrzesniewski et al., 
1997), but research has not learned which individual attributes might be associated with different work orientations. Identifying the respective predictor attributes will further understanding of the work orientation construct. As a general, abstract construct, work orientation potentially relates to many individual attributes because work causes individuals to confront many conditions that invoke diverse attributes. Categories of individual attributes that may be associated with work orientations include individuals' personalities, commitment attitudes, and work motives. Because workplace outcomes are the result of cumulative behaviors, personality variables are likely to influence them and may relate to work orientation (Buss \& Craik, 1983). Within the career development literature, studies show proactive personality has a significant relationship with work outcomes across occupations and organizations (Becherer \& Maurer, 1999; Kirkman \& Rosen, 1999; Siebert, Crant, \& Kraimer, 2001).

Differences in commitment attitudes are likely to relate to work orientation since an individual may link his or her purpose for work to the preferred target of efforts. One's work orientation may also influence overall motivation and performance; therefore, attributes associated with intrinsic motivation deserve attention. The attributes examined here include proactive personality, two commitment attitudes, and two work motives. Figure 1 presents the specific individual attributes, work orientations, and their hypothesized relationships.

\section{Proactive Personality}

Bateman and Crant (1993) developed the construct of proactive personality, defined as a stable dispositional tendency to take personal initiative across a range of activities and situations. People who are highly proactive identify opportunities, act upon them, and persevere until they are able to change their current circumstances (Seibert, Crant, \& Kraimer, 2001). Proactive individuals are likely to engage in career management and pursue self-improvement activities in an effort to shape their work environments. The lack of a proactive personality may prevent a person from exploring more meaningful or satisfying work options. Individuals with a high job orientation are primarily interested in the material benefits work provides, and thus would not likely seek intrinsically rewarding work (Wrzesniewski et al., 1997). This suggests an inverse relationship between proactive personality and job orientation. Career progress is important to those with a high career orientation, and this pursuit requires acting on the environment, attempting to influence opportunities and rewards. Therefore, we expect proactive personality to be an individual attribute associated with a career work orientation. Wrzesniewski and Dutton's (2001) model of job crafting suggests employees can seek opportunities in task, cognitive, or relational facets of their work to define the meaning of their work. A proactive personality would clearly facilitate this process, including for those with a high calling orientation attempting to craft their work to increase meaningfulness. Therefore, we propose the following:

Hla: Proactive personality is negatively related to job orientation.

H1b: Proactive personality is positively related to career orientation.

H1c: Proactive personality is positively related to calling orientation. 
Figure 1:

Proposed Framework for Work Orientation Relationships

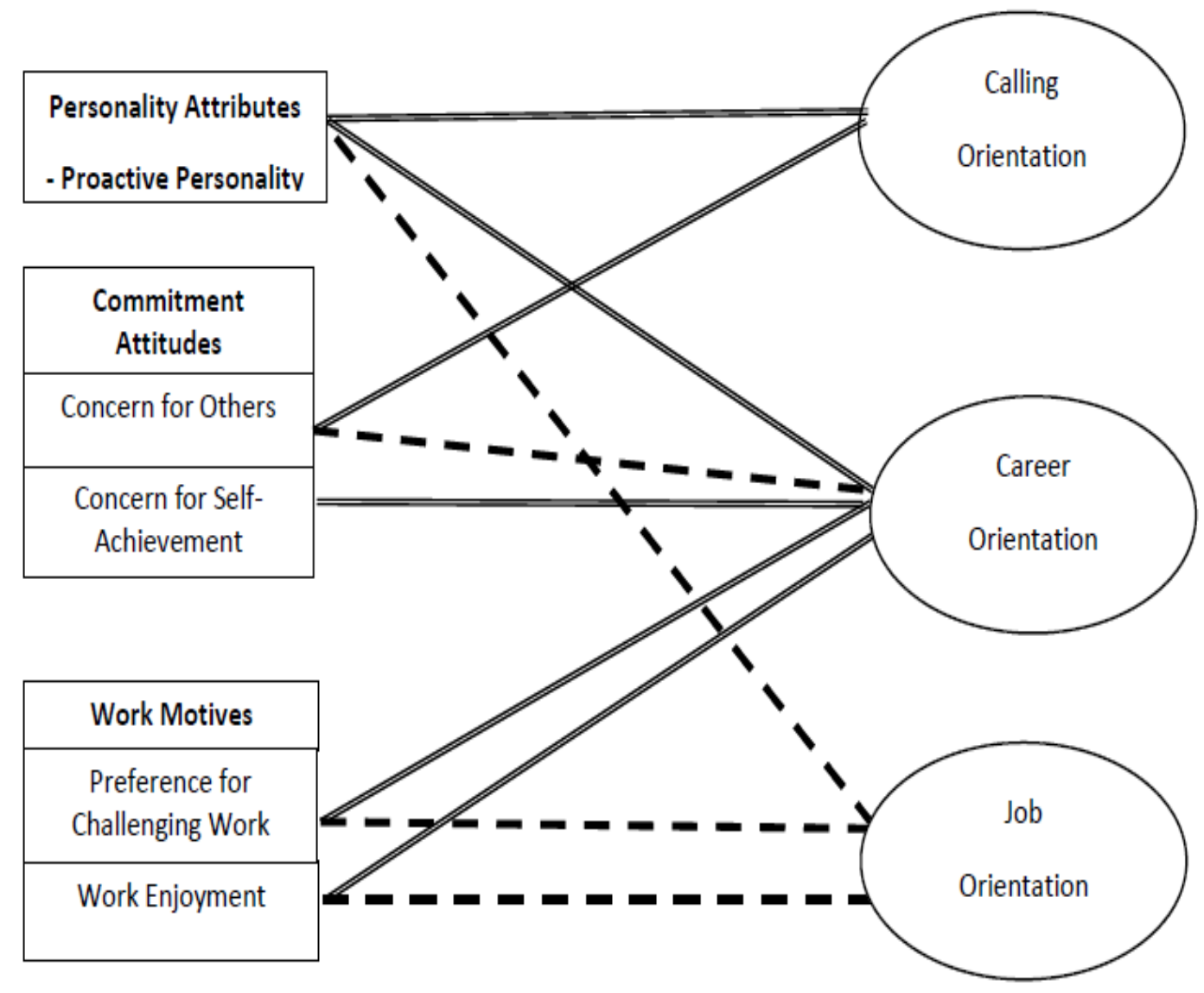

Note: Single dotted line represents a negative relationship Double lines represent positive relationships

\section{Commitment Attitudes}

Individuals likely link their purposes for work to preferred goals, thereby generating commitment attitudes. Self-directed individuals have a primary focus on serving their own ends while other-directed individuals possess a commitment to efforts that serve others. Meglino and Korsgaard (2006) suggested that self- and other-oriented goals have an attention focusing function. Work orientation potentially shares this attention focusing, such that individuals with a high career orientation focus on one's self while individuals possessing a high calling orientation emphasize others.

Concern for others. Work is a social enterprise not only because task performance involves interacting with others but also because enacting work activities often has social consequences. Descriptions of job, career, and calling orientations suggest that a concern for others would distinguish these three work orientations. Bellah et al. (1985) conceptualized calling as "a commitment to a profession in which a person is linked to the larger community and contributes 
to the common good" (1985; p. 66). Researchers have conceptualized calling as socially valuable work (Wrzesniewski et al., 1997) or devotion to a craft which enriches the lives of the public (Dobrow, 2006). Integral to the concept is a focus on others, a sense of responsibility or obligation an individual feels for the greater good. Weiss, Skelley, Hall, and Haughey (2003) discussed how individuals with a high calling orientation maintained an awareness of how their work served others. Whereas we would expect a concern for others to relate positively to a calling orientation, this would not be the case for the other two work orientations. Individuals with a high job orientation view work as an instrumental activity, and therefore having a concern for others would not constitute a purpose for working. Individuals with a high career orientation likely view work as a means to enhance the self and are unlikely to be concerned with work peers or those external to the organization except insofar as those others present obstacles. Thus, these hypotheses receive attention in this study:

H 2a: Concern for others is not significantly related to job orientation

$H 2 b$ : Concern for others is negatively related to career orientation

$H$ 2c: Concern for others is positively related to calling orientation.

Concern for self-achievement. Career theories (Hughes, 1958) focus on one's own achievement and success. Similarly, many motivation theories, such as Vroom's (1964) expectancy theory, derive from an individually focused view that suggests rational self-interest drives work behaviors as individuals pursue goals that maximize one's utility based on rational calculation. A person with a high career orientation likely focuses on his or her own achievement at work because of this self-commitment, and therefore we expect a positive relationship between concern for self-achievement and career orientation. Consistent with Bellah and his colleagues' (1985) conceptualization of calling orientation, a growing body of research supports the view that interpersonal relationships play a key role in enabling employees to experience their work as important and a source of life meaning (Bradbury \& Lichtenstein, 2000; Wrzesniewski, Dutton, $\&$ Debebe, 2003). With a focus on others to create meaningfulness from one's work, a person with a high calling orientation will not be as focused on his or her own self-achievement. Individuals with a high job orientation view work as an instrumental activity; therefore, achievement will not be a purpose for working. Since a primary focus on self-achievement does not characterize either a job orientation or a calling work orientation, we hypothesize no significant relationship between self-achievement emphasis and those two work orientations.

H 3a: Concern for self-achievement is not significantly related to job orientation. $H$ 3b: Concern for self-achievement is positively related to career orientation. $H$ 3c: Concern for self-achievement is not significantly related to calling orientation.

\section{Work Motives}

Roberson's (1990) initial theorizing about work orientation suggested that individual differences about work's purposes were associated with intrinsic and extrinsic motivation. Amabile, Hill, Hennessey, and Tighe (1994) indicated intrinsic and extrinsic motives are stable, enduring individual characteristics, similar to work orientation, and their study revealed that intrinsic motivation consisted of two motives, challenge and enjoyment. Wrzesniewski and her 
associates (1997) subsequently identified challenging work as potentially enriching a career work orientation.

Challenging work. For extrinsically oriented employees, such as those with a high job orientation, the feeling of accomplishment with completing challenging tasks is short-lived (Vansteenkiste, Neyrinck, Niemiec, Soenens, De Witte, \& Van den Broeck, 2007) and presumably does not positively engage the meaning of work. For someone with a high job orientation, he or she would likely experience work challenges burdensome. We would expect a different relationship between challenging work and career orientation. Individuals with a high career orientation may prefer challenging work because it provides opportunities to test themselves against other competent peers (Spence \& Helmreich, 1983) and to differentiate themselves from others (Kanfer \& Heggestad, 1997; Rynes \& Connerley, 1993). Completing challenging tasks also enhances psychological success and a sense of achievement (Elliot \& Harackiewicz, 1996), characteristics of a career orientation. The components of a calling orientation, social value and fulfillment, do not necessarily appear connected to a preference for challenging work. Logically, we would not expect intrinsically challenging work to foster a calling work orientation, nor would such a work orientation generate a preference for challenging work. Thus, we do not expect a relationship between preference for challenging work and a calling work orientation.

H 4a: Preference for challenging work is negatively related to job orientation. $H$ 4b: Preference for challenging work is positively related to career orientation. $\mathrm{H} 4 \mathrm{c}$ : Preference for challenging work is not significantly related to calling orientation.

Work enjoyment. Work enjoyment refers to the level of pleasure derived from work (Johnstone \& Johnston, 2005). Self-determination theory (SDT; Deci \& Ryan, 2000) suggests that focusing on material rewards, characteristic of a job orientation, detracts from achieving satisfaction of individual needs for autonomy, competence, and relatedness. A recent SDT study found that individuals with a preference for extrinsic rewards reported lower job and life satisfaction outcomes (Vansteenkiste et al., 2007), and Wrzesniewski et al. (1997) discovered that respondents with a higher job orientation had lower levels of job satisfaction and tended not to find their work rewarding. These results imply that individuals with a high job orientation will have a negative view of work and not enjoy it. Those individuals with a higher career work orientation will be more likely to experience work enjoyment. Deriving pleasure from their work, they would seek to build a career to sustain and enhance that enjoyment, and alternately, experiencing work success would generate career enjoyment. Thus whichever causal process obtains, we would expect work enjoyment to relate positively to career work orientation. Regarding calling, work enjoyment does not appear associated with a sense of work meaningfulness characteristic of a higher calling orientation. Bonebright, Clay, and Ankenmann (2000) found that individuals high in work drive and work enjoyment reported high work involvement but not life satisfaction or a sense of purpose. Oates, Hall, and Anderson (2005) indicated that some university professors possessed a high calling orientation even when work enjoyment was missing. Similarly, some employees interpret their work as meaningful even if they do not experience it as enjoyable (Wrzesniewski \& Dutton, 2001; Wrzesniewski, Dutton, \& Debebe, 2003). Therefore, 
H 5a: Work enjoyment is negatively related to job orientation.

$H$ 5b: Work enjoyment is positively related to career orientation.

H 5c: Work enjoyment is not significantly related to calling orientation.

\section{Respondents and Procedures}

\section{Methods}

To investigate the variables associated with specific work orientations, we studied workers within the automobile industry. We chose a simple organization to minimize structural influences on work meaning, and a single organization to minimize variances in organizational and industry conditions. Our goal was to explore the attributes of individuals with potentially different work meanings doing somewhat similar work in a similar organizational environment. Locations varied however.

We utilized a cross-sectional design to test the hypotheses presented using an Internet based survey. Using work email addresses of potential participants supplied by the employer, we emailed 635 employees, 404 employees working in branch locations on the East Coast of the United States and 231 office employees working primarily in the Midwest. We sent emails to all office and branch level employees at the selected locations in an effort to include respondents at various levels of income, education, and experience.

Study participants consisted of 74 office employees and 177 branch employees for an overall response rate of $40 \%$. We conducted a power analysis and determined the sample size of 251 achieved $85 \%$ power to detect a small to medium effect size $\left(f^{2}=.05\right.$, Cohen, 1992) at a significance level $(\alpha)$ of 0.05 . Survey respondents were $56 \%$ female, had a mean age of 41.0 years $(\mathrm{sd}=11.2)$, and a mean annual salary of $\$ 46,895(\mathrm{sd}=\$ 26,610)$. Almost all of the employees in the sample population were Caucasian and U.S. born.

\section{Measures}

Work orientation. We measured work orientation using a modified version of Wrzesniewski's (1999) work orientation scale with Yugo's (2006) five-point Likert response format. The modification involved incorporating two items, "I find my work rewarding" and "I greatly anticipate weekends, I say 'Thank God it's Friday” (Tosti, 2008; Wrzesniewski et al., 1997). These two items increased the content validity of the work orientation scale, had high factor loadings in prior studies, and are consistent with modifications made by Wrzesniewski in other studies measuring work orientation (Wrzesniewski personal communication, 2008). We calculated an average score for each of the three work orientations for each respondent for use in data analysis.

As noted in Table 1, the reliabilities for the three-item job orientation scale, the two-item career scale, and the seven-item calling scale, as measured by Cronbach's alpha, were $.533, .651$, and .777 respectively. While two of the work orientation reliabilities were somewhat low due to the limited number of items, all but one of the inter-item correlations, an appropriate reliability measure with few items constituting a scale (Cortina, 1993), exceed 30 (Robinson, Shaver, \& Wrightsman, 1991). We also reviewed the items comprising each factor, noting they were substantively consistent with the definitions of job, career, and calling orientations found in the work orientation literature (Bellah et al., 1985; Wrzesniewski et al., 1997). 
Proactive personality. We measured proactive personality using Bateman and Crant's (1993) ten item proactive personality scale. Sample items included, "I am constantly on the lookout for new ways to improve my life" and "If I see something I don't like, I fix it."

Concern for others. Our measure of concern for others was a subscale of Ravlin and Meglino's (1987) comparative emphasis scale (CES). The CES was a forced-choice scale asking respondents to choose among twenty-four pairs of statements representing the four workplace values of concern for others, self-achievement, fairness, and honesty/integrity. We used a forcedchoice measure due to the socially desirable nature of the concern for others construct. Statements representing the concern for others subscale included, "Trying to help a fellow worker through a difficult time" and "Sharing information and ideas which others need to do their job". The CES is a fully ipsative measure, measuring the values most important to each individual relative to the other values, and thus we used the full scale.

Concern for self-achievement. We measured concern for self-achievement using the concern for self-achievement subscale of Ravlin and Meglino's (1987) comparative emphasis scale (CES). Statements representing the concern for self-achievement subscale included, "Taking on additional tasks to get ahead" and "Taking on more responsibility to get ahead in an organization".

Preference for challenging work. We measured preference for challenging work using Amabile et al.'s (1994) five-item Work Preference Inventory challenge subscale. Subscale items included, "I enjoy trying to solve complex problems" and "I prefer work I know I can do well over work that stretches my abilities" (reverse scored).

Work Enjoyment. Our work enjoyment measure derived from another Amabile et al. (1994) subscale. This enjoyment subscale contained ten items including, "What matters most to me is enjoying what I do" and "I enjoy doing work that is so absorbing that I forget everything else".

Control variables. Earlier studies found positive relationships between work orientation and age (Charles \& James, 2003; Wrzesniewski et al., 1997), between work orientation and income (Davidson \& Caddell, 1994; Wrzesniewski et al., 1997), and between career outcomes and gender (Fagan, 2001; Hakim, 1991); therefore, we included these variables as control variables in this study. We measured age by asking for age in years. For annual income, we used 13 categories from less than $\$ 10,000$ per year to more than $\$ 250,000$ per year and utilized the midpoint of each income range for data analysis.

Davidson and Caddell (1994) noted a positive relationship between perceived employment security and calling orientation. We measured and controlled for employment security using Brandes, Castro, James, Martinez, Matherly, Ferris, and Hochwarter's (2008) four-item scale. Scale items included "I am waiting for the next shoe to fall in that I am wondering if my job will be eliminated".

\section{Analysis}

We performed hierarchical multiple regression using the same statistical tests for each set of hypotheses because all five predictors and all three dependent variables were measured using 
interval scales. We used two regression models to test each hypothesis. The first model contained only the covariates (controls) of age, income, and employment security, and the second model contained the covariates and the given predictor.

\section{Results}

\section{Work Orientation}

Given the inconsistent conceptualizations of the work orientation construct found in prior research (Davidson \& Caddell, 1994; Wrzesniewski, 1999; Wrzesniewski et al., 1997), we conducted an exploratory factor analysis using oblique rotation to examine the factor structure of the work orientation dimensionality. This analysis produced three factors with eigenvalues greater than $1.0(3.453,1.686$, and 1.279$)$ and the next highest eigenvalue at .882 , clearly indicating three factors. To explore further the appropriateness of the three-factor model, we conducted a confirmatory factor analysis comparing the three-factor solution to one-factor and two-factor solutions. The results of chi-square tests indicated the three-factor model of work orientation fit better than the one-factor and the two-factor combined models ${ }^{1}$.

Distribution of work orientations. Because the conceptualization of work orientation does not assume the three orientations are mutually exclusive, such that an individual may hold more than one work orientation, it was desirable to examine the distribution of primary work orientations among sample respondents. It was also important to assure that no occupational or industrial bias existed. To determine the primary work orientation of respondents, we compared each study participant's average score for job, career, and calling work orientation, noting the highest average-scoring work orientation for each participant. Our samples of direct service branch employees and office support employees showed similar proportions of primary job, career, and calling orientations. We also noted similar proportions of primary work orientation for males and females. Overall, $31.5 \%$ of the respondents indicated job orientation as his or her primary orientation, $32.3 \%$ career orientation, $29.1 \%$ calling orientation, and $7.2 \%$ of respondents did not possess a primary work orientation.

\section{Hypotheses Testing}

Table 1 presents means, standard deviations, reliabilities, and correlations for the study variables for all respondents. Age and felt employment security were systematically associated with work orientation. Respondents with a higher career orientation score tended to be younger $(\mathrm{r}=-.473, \mathrm{p}<.001)$; respondents with a higher calling orientation score tended to be older $(\mathrm{r}=$ $.233, \mathrm{p}<.001)$ and felt more secure in their employment $(\mathrm{r}=.373, \mathrm{p}<.001)$, and respondents with a higher job orientation score tended to feel less secure in their employment $(r=-.164, p<.01)$. Relationships between the control variable, log of annual income, and the three work orientation variables did not meet conventional levels of significance.

Test results indicate the relationships among the variables were linear and outliers, multicollinearity, skewness, and kurtosis were not causes for concern. For each regression analysis conducted, we determined that the standardized residuals were normally distributed and

\footnotetext{
${ }^{1}$ Work orientation items comprising each factor, the factor correlation matrix, and LISREL fit statistics for CFA models tested are available from the corresponding author upon request.
} 
the assumption of homoscedasticity was not violated. Thus the data met the assumptions for regression, indicating hierarchical multiple regression was appropriate to use for this data. Table 2 summarizes the results of the hypotheses testing.

Hypotheses 1a-c predicted a negative relationship between proactive personality and job orientation and a positive relationship between proactive personality and both career and calling orientations. Table 2 indicates that the relationship between proactive personality and job orientation is not significant $(\mathrm{t}=.347, \mathrm{p}=.729)$, and therefore hypothesis 1a is not supported. The results showed a significant positive relationship between proactive personality and career orientation $(\mathrm{t}=4.525, \mathrm{p}<.001)$ and calling orientation $(\mathrm{t}=2.948, \mathrm{p}=004)$, indicating support for hypotheses $1 \mathrm{~b}$ and $1 \mathrm{c}$.

Hypotheses $2 \mathrm{a}-\mathrm{c}$ predicted a non-significant relationship between concern for others and job orientation, a negative relationship between concern for others and career orientation, and a positive relationship between concern for others and calling orientation. The Table 2 results show the relationship between concern for others and job orientation does not meet conventional levels of significance $(\mathrm{t}=-0.607, \mathrm{p}=.545)$, thus supporting hypothesis $2 \mathrm{a}$. However the relationship between concern for others and career orientation $(t=.011, p=.991)$ and that between concern for others and calling orientation $(t=-0.291, p=.771)$ were above conventional levels of significance, so that hypotheses $2 b$ and $2 c$ were not supported.

Hypotheses $3 \mathrm{a}-\mathrm{c}$ predicted a non-significant relationship between concern for selfachievement and both job and calling orientations, and a positive relationship between concern for self-achievement and career orientation. The results showed the relationships between concern for self-achievement and both job orientation $(\mathrm{t}=-0.441, \mathrm{p}=.441)$ and calling orientation $(\mathrm{t}=.548, \mathrm{p}=.584)$ did not reach statistical significance, thus supporting hypotheses $3 \mathrm{a}$ and $3 \mathrm{c}$. The results showed a positive relationship between concern for self-achievement and career orientation $(\mathrm{t}=3.081, \mathrm{p}=.002)$, thereby providing support for hypothesis $3 \mathrm{~b}$.

Hypotheses $4 \mathrm{a}-\mathrm{c}$ predicted a negative relationship between preference for challenging work and job orientation, a positive relationship between preference for challenging work and career orientation, and a non-significant relationship between preference for challenging work and calling orientation. The results of the multiple regression analysis showed a significant negative relationship $(\mathrm{t}=-2.544, \mathrm{p}=.012)$ between job orientation and preference for challenging work, reflecting support for hypothesis $4 \mathrm{a}$. Hypotheses $4 \mathrm{~b}$ and $4 \mathrm{c}$ did not receive support, with results indicating a non-significant relationship between challenging work preference and career orientation $(\mathrm{t}=1.516, \mathrm{p}=.131)$ and a positive significant association between preference for challenging work and calling orientation $(\mathrm{t}=2.852, \mathrm{p}=.005)$.

Hypotheses $5 \mathrm{a}-\mathrm{c}$ predicted a negative relationship between work enjoyment and job orientation, a positive relationship between work enjoyment and career orientation, and a nonsignificant relationship between work enjoyment and calling orientation. The results showed the relationship between work enjoyment and job orientation $(\mathrm{t}=1.856, \mathrm{p}=.065)$ was just above standard levels of significance, and a positive relationship emerged between work enjoyment and calling orientation $(\mathrm{t}=3.046, \mathrm{p}=.003)$. Therefore, hypotheses $5 \mathrm{a}$ and $5 \mathrm{c}$ did not receive support. The results showed a positive relationship between work enjoyment and career orientation score $(\mathrm{t}=4.870, \mathrm{p}>.001)$, reflecting support for hypothesis $5 \mathrm{~b}$. 
INDIVIDUAL ATTRIBUTES AND WORK ORIENTATIONS

Table 1

Means, Standard Deviations, Reliabilities, and Inter-correlations of Study Variables $(n=251)$

\begin{tabular}{|c|c|c|c|c|c|c|c|c|c|c|c|c|c|c|}
\hline & M & SD & 1 & 2 & 3 & 4 & 5 & 6 & 7 & 8 & 9 & 10 & 11 & 12 \\
\hline $\begin{array}{l}\text { 1. Job } \\
\text { Orientation } \\
\text { 2. Career }\end{array}$ & 3.39 & 0.76 & (.53) & & & & & & & & & & & \\
\hline $\begin{array}{l}\text { Orientation } \\
\text { 3. Calling }\end{array}$ & 3.30 & 0.94 & 0.068 & (.65) & & & & & & & & & & \\
\hline $\begin{array}{c}\text { Orientation } \\
\text { 4. Proactive }\end{array}$ & 3.24 & 0.68 & $-0.366^{\star \star \star}$ & 0.005 & $(.78)$ & & & & & & & & & \\
\hline $\begin{array}{l}\text { Personality } \\
\text { 5. Concern for }\end{array}$ & 5.32 & 0.82 & 0.036 & $0.320^{\star * *}$ & $0.171^{* *}$ & $(.89)$ & & & & & & & & \\
\hline $\begin{array}{l}\text { Others } \\
\text { 6. Concern for }\end{array}$ & 0.21 & 0.41 & 0.038 & $-0.132^{*}$ & 0.038 & -0.118 & (n.a.) & & & & & & & \\
\hline $\begin{array}{l}\text { Self } \\
\text { 7. Pref for } \\
\text { Challenging }\end{array}$ & 0.27 & 0.45 & -0.014 & $0.223^{\star * \star}$ & 0.010 & $0.142^{*}$ & $-0.341^{\star \star \star}$ & (n.a.) & & & & & & \\
\hline $\begin{array}{l}\text { Work } \\
8 . \text { Work }\end{array}$ & 3.81 & 0.62 & $-0.181^{* *}$ & $0.129^{*}$ & $0.212^{\star *}$ & $0.288^{\star \star *}$ & -0.101 & 0.070 & $(.77)$ & & & & & \\
\hline Enjoyment & 3.84 & 0.44 & 0.097 & $0.256^{* \star *}$ & $0.199^{* \star}$ & $0.483^{* \star *}$ & 0.024 & 0.036 & $0.323^{* * *}$ & $(.72)$ & & & & \\
\hline $\begin{array}{l}\text { 9. Gender } \\
\text { 10.Age in }\end{array}$ & 0.56 & 0.50 & 0.078 & -0.023 & -0.086 & -0.079 & 0.072 & -0.014 & -0.093 & -0.071 & (n.a.) & & & \\
\hline Years & 41.0 & 11.18 & $-0.165^{\star \star}$ & $-0.473^{* \star *}$ & $0.233^{* \star *}$ & $-0.126^{*}$ & -0.018 & $-0.130^{*}$ & -0.030 & 0.005 & -0.057 & (n.a.) & & \\
\hline $\begin{array}{l}\text { 11.Log Annual } \\
\text { Income } \\
\text { 12.Employment }\end{array}$ & 4.63 & 0.25 & -0.030 & -0.069 & 0.101 & 0.000 & 0.020 & -0.120 & 0.040 & -0.081 & $-0.331^{* *}$ & $0.282^{\star * *}$ & (n.a.) & \\
\hline Security & 5.11 & 1.19 & $-0.164^{\star \star}$ & 0.011 & $0.373^{* \star}$ & 0.109 & 0.068 & 0.068 & $0.127^{\star}$ & 0.051 & -0.077 & -0.004 & 0.027 & $(.79)$ \\
\hline
\end{tabular}

Note: All scale measures were based on a 5-point scale except for proactive personality and job security, which were based on a 7-point scale. Gender coded as female $=1,0=$ male. Concern for others (CFO) coded as $1=\mathrm{CFO}$ as primary value, $0=\mathrm{CFO}$ not primary value. Concern for self $(\mathrm{CFS})$ coded as $1=\mathrm{CFS}$ as primary value, $0=$ CFS not primary value. Values along the diagonal are Cronbach's alpha reliabilities. $* \mathrm{p}<.05, * * \mathrm{p}<.01, * * * \mathrm{p}<.001$ 


\section{INDIVIDUAL ATTRIBUTES AND WORK ORIENTATIONS}

Table 2

Results of Multiple Regression Analysis for the Effects of Independent Variables on Work Orientation $(n=240)$

\begin{tabular}{|c|c|c|c|c|c|c|c|c|c|c|c|c|c|c|c|c|c|c|}
\hline & \multicolumn{6}{|c|}{ Proactive Personality } & \multicolumn{6}{|c|}{ Concern for Others } & \multicolumn{6}{|c|}{ Concern for Self-Achievement } \\
\hline & \multicolumn{2}{|c|}{$\begin{array}{c}\text { Job Orientation } \\
\beta\end{array}$} & \multicolumn{2}{|c|}{$\begin{array}{c}\text { Career } \\
\text { Orientation } \\
\beta\end{array}$} & \multicolumn{2}{|c|}{$\begin{array}{c}\text { Calling } \\
\text { Orientation } \\
\beta\end{array}$} & \multicolumn{2}{|c|}{$\begin{array}{c}\text { Job Orientation } \\
\text { B }\end{array}$} & \multicolumn{2}{|c|}{$\begin{array}{c}\text { Career } \\
\text { Orientation } \\
\beta\end{array}$} & \multicolumn{2}{|c|}{$\begin{array}{c}\text { Calling } \\
\text { Orientation } \\
\beta\end{array}$} & \multicolumn{2}{|c|}{$\begin{array}{c}\text { Job Orientation } \\
\beta\end{array}$} & \multicolumn{2}{|c|}{$\begin{array}{c}\text { Career } \\
\text { Orientation } \\
\beta\end{array}$} & \multicolumn{2}{|c|}{$\begin{array}{c}\text { Calling } \\
\text { Orientation } \\
\beta\end{array}$} \\
\hline Age & -0.195 & ** & -0.472 & $* * *$ & 0.285 & *** & -0.195 & ** & -0.511 & $* * *$ & 0.259 & $* * *$ & -0.202 & ** & -0.493 & $* * *$ & 0.261 & *** \\
\hline Log of Annual Income & 0.023 & & 0.066 & & 0.023 & & 0.024 & & 0.080 & & 0.023 & & 0.011 & & 0.096 & & 0.026 & \\
\hline Employment Security & -0.158 & * & -0.047 & & 0.369 & $* * *$ & -0.159 & * & -0.027 & & 0.367 & $* * *$ & -0.154 & * & -0.042 & & 0.366 & *** \\
\hline $\mathrm{R}$ & 0.248 & & 0.553 & & 0.484 & & 0.250 & & 0.495 & & 0.454 & & 0.249 & & 0.524 & & 0.455 & \\
\hline $\mathrm{R}^{2}$ & 0.062 & & 0.306 & & 0.234 & & 0.063 & & 0.245 & & 0.206 & & 0.062 & & 0.274 & & 0.207 & \\
\hline Adjusted R2 & 0.046 & & 0.294 & & 0.221 & & 0.047 & & 0.232 & & 0.192 & & 0.046 & & 0.262 & & 0.193 & \\
\hline $\mathrm{F}$ & 3.858 & $* *$ & 25.857 & $* * *$ & 17.948 & $* * *$ & 3.924 & $* *$ & 19.077 & $* * *$ & 15.238 & $* * *$ & 3.878 & $* *$ & 22.220 & $* * *$ & 15.306 & *** \\
\hline \multicolumn{19}{|l|}{ Step 2.} \\
\hline Predictor Variable & 0.022 & & 0.250 & $* * *$ & 0.171 & $* *$ & -0.039 & & 0.001 & & -0.017 & & -0.028 & & 0.174 & ** & 0.032 & \\
\hline $\mathrm{t}$ & 0.347 & & 4.525 & $* * *$ & 2.948 & $* *$ & -0.607 & & 0.011 & & -0.291 & & -0.441 & & 3.081 & ** & 0.548 & \\
\hline $\mathrm{R}^{2}$ Change & 0.000 & & 0.060 & & 0.028 & & 0.001 & & 0.000 & & 0.000 & & 0.001 & & 0.029 & & 0.001 & \\
\hline $\mathrm{F}$ - Change & 0.121 & & 20.475 & $* * *$ & 8.694 & $* *$ & 0.368 & & 0.000 & & 0.085 & & 0.194 & & 9.491 & $* *$ & 0.300 & \\
\hline
\end{tabular}

Note: The standardized coefficients $(\beta)$ presented are for the final (second) model with all variables included. No differences in significance were noted between the first and second models. ${ }^{*} \mathrm{p}<.05, * * \mathrm{p}<.01, * * * \mathrm{p}<.001$ 


\section{INDIVIDUAL ATTRIBUTES AND WORK ORIENTATIONS}

Table 2 (continued)

Results of Multiple Regression Analysis for the Effects of Independent Variables on Work Orientation $(n=240)$

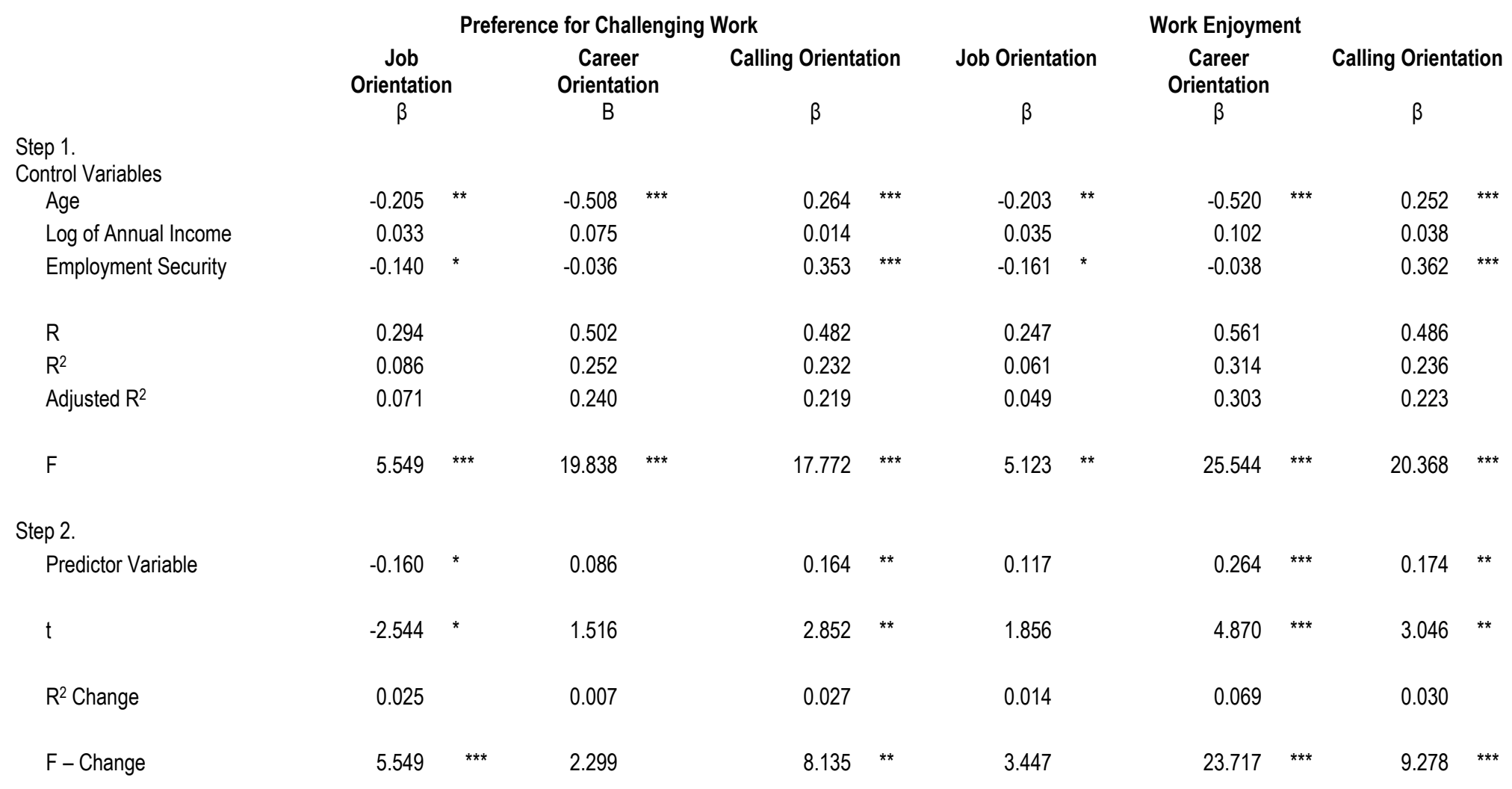

Note: The standardized coefficients $(\beta)$ presented are for the final (second) model with all variables included. No differences in significance were noted between the first and second models. $* \mathrm{p}<.05, * * \mathrm{p}<.01, * * * \mathrm{p}<.001$ 


\section{Discussion}

This study contributes to the understanding of the meaning of work in several important ways. It shows preference for challenging work appears to differentiate job, career, and calling orientations. The perception of one's employment security is more of an influence on differences in work orientation than one's work enjoyment. Finally, consistent with prior studies, this study found age was associated with individuals' work orientation profiles, but in distinction to prior research, this study found income was not associated with work orientation.

Guided by prior research this study hypothesized that the commitment attitude, concern for others, would differentiate job, career, and calling orientations. However, the results here did not support a positive relationship between calling orientation and concern for others. Rather, this study suggests that the work motive of preference for challenging work differentiates job, career and calling work orientations. The results imply an individual who avoids challenging work has a high job orientation score, a person who prefers challenging work has a high calling orientation score, and a person who neither prefers nor avoids challenges has a high career orientation score. These results are consistent with work on optimal experience (Delle Fave \& Massimini, 2003) in which participants reported that a preference for challenges provided meaning in life regardless of the specific activity experienced. Viewing a calling orientation in terms of concerns for others limits it primarily to "helping" occupations (Maslach, 1982), but our results suggest a broader view. Understanding calling in terms of preference for challenging work is consistent with Bellah et al.'s (1985) assertion that anyone potentially can see his or her work as a calling.

Consistent with Davidson and Caddell (1994), the results of this study revealed individuals with high job orientation scores felt less secure about their future employment than individuals with high career or calling orientation scores. This suggests along with the Wrzesniewski et al. (1997) discovery of job orientation's association with lower performance and job and life satisfaction that work organizations could beneficially act to lessen fears of employment insecurity. Those with a high calling orientation score perceived employment security positively. All three work orientations related positively to work enjoyment, although one of the three relationships fell just below statistical significance. It appears whether a person enjoys work or not is not an attribute that explains variations in work meaning.

Our findings related to age suggest a person's work orientation profile may change gradually over the course of a person's work life. Our income finding may be somewhat counterintuitive and contrary to prior theorizing (Hall \& Chandler, 2005), but it suggests that a lack of personal resources does not prohibit an individual from having a high calling orientation.

\section{Implications}

This study advances the idea that identifiable individual attributes determine in part the meaning one attaches to work. This study suggests implications for career theories, which advocate a model of matching individual traits to work environments to determine preferred vocational choice and to maximize work outcomes (Betz, Fitzgerald, \& Hill, 1989; Holland 1992). Given this study's findings of individual attributes' associations with the three work orientations, researchers may want to incorporate work orientations in career theories to improve individual fit. Specifically, the addition of work orientations to Holland's (1992) personality-job fit theory would add a value component to the individual and occupational alignments predicted 
by the theory. Practically speaking, this study's recognition of three distinct work orientations suggests that career counselors can add work orientations to their use of interests and personality predispositions in advising individual and organizational clients about employment congruence. Similarly human resource departments can make use of work orientations in selection, placement and training activities, to match individuals with organizational cultures. In addition, some of this study's specific findings are applicable to career specialists. For example, a calling orientation is associated with a proactive personality and a preference for challenging work, individual attributes measurable by career specialists.

Understanding the results of this study requires recognition of certain limitations. The design of this study was cross-sectional and not longitudinal, thereby preventing causal inference. This study utilized an ethnically homogeneous sample. As such, the results of this study are not generalizable to more demographically diverse groups of domestic workers or work groups outside of the United States. Another limitation of this research involves the subscales used to measure job and career orientations. The job and career orientation scales had internal consistency reliability somewhat below conventional levels, as measured by Cronbach's alpha $(\alpha)$. These reliabilities define a need for psychometric improvement of these measures. Despite these limitations, this research offers contributory results and encourages opportunities for future research.

To develop the work orientation concept we encourage additional studies. The stability of work orientation as a work value deserves future research inquiry. We need longitudinal studies exploring how work orientations develop over time to understand how the meaning of work might change and whether such changes derive from lifespan phase, generational characteristics, or socioeconomic conditions. Finally, because this study utilized a relatively homogeneous sample from a single organization, additional studies should incorporate diverse occupational groups to understand if the work orientation concept promises generalizability.

In conclusion, prior research indicated differences in individual and organizational outcomes associated with variations in the meaning individuals experience from their paid employment (Claes \& RuizQuintanilla, 1994; George \& Jones, 1996; Wrzesniewski et al., 1997). The present study extends this research by specifying the attributes associated with various meanings of work. Our results indicate that preference for challenging work differentiates one's work orientation, rather than work enjoyment, concern for others, or income. While this study encourages application of the work orientation construct, we need continued research to understand better the attributes associated with the meaning of work.

\section{References}

Amabile, T. M., Hill, K. G., Hennessey, B. A., \& Tighe, E. M. (1994). The work preference inventory: Assessing intrinsic and extrinsic motivational orientations, Journal of Personality and Social Psychology, 66(5), 950-967.

Bateman, T. S., \& Crant, J. M. (1993). The proactive component of organizational behavior. Journal of Organizational Behavior, 14, 103-118.

Becherer, R. C., \& Maurer, J. G. (1999). The proactive personality disposition and entrepreneurial behavior among small company presidents, Journal of Small Business Management, 37(1), 28-36. 
Bellah, R. N., Madsen, R., Sullivan, W. M., Swidler, A., \& Tipton, S. M. (1985). Habits of the Heart: Individualism and Commitment in American Life. Los Angeles: University of California Press.

Betz, N. E., Fitzgerald, L. F., \& Hill, R. E. (1989). Trait factor theories: Traditional cornerstone of career theory. In M. B. Arthur, D. T. Hall, \& B. S. Lawrence Handbook of Career Theory, New York: Cambridge University Press, 26-39.

Bloch, D. P. (1997). Spirituality, intentionality and career success: the quest for meaning. In Bloch, D.P., \& Richmond, L.J. (Eds.) Connections Between Spirit and Work in Career Development, Palo Alto, CA: Davies-Black.

Bonebright, C., Clay, D., \& Ankenmann, R. (2000). The relationship of workaholism with worklife conflict, life satisfaction, and purpose in life. Journal of Counseling Psychology, 47(4), 469-477.

Brandes, P., Castro, S. L., James, M. S. L., Martinez, A. D., Matherly, T. A., Ferris, G. R., \& Hochwarter, W. A. (2008). The interactive effects of job insecurity and organizational cynicism on work effort following a layoff. Journal of Leadership and Organizational Studies, 14, 233-247.

Bradbury, H., \& Lichtenstein, B. M. B. (2000). Relationality in organizational research: Exploring the space between. Organization Science, 11, 551-564.

Brief, A., \& Nord, W. (1990). Meanings of Occupational Work: A Collection of Essays. Lexington, MA: Lexington Books.

Buss, D. M., and Craik, K. H. (1983). The act of frequency approach to personality. Psychological Review, 90, 10-126.

Cable, D. M ., \& Edwards, J. R. (2004). Complementary and supplementary fit: A theoretical and empirical integration. Journal of Applied Psychology, 89(5), 822-834.

Cardador, M. T. (2008). Re-orienting the career orientation: Implications for hybrid work orientations. Paper presented at the annual meeting of the Academy of Management, Anaheim, CA.

Chalofsky, N. (2003) An emerging construct for meaningful work. Human Resource Development International, 6(1), 69-83.

Charles, N., \& James, E. (2003). Gender and work orientations in conditions of job insecurity. British Journal of Sociology, 2, 239-257.

Claes, R., \& Ruiz Quintanilla, S. A. (1994). Initial career and work meaning in seven European countries. The Career Development Quarterly, 42, 337-352.

Cohen, J. (1992). A power primer. Psychological Bulletin, 112(1), 155-159.

Cortina, J. M. (1993). What is coefficient alpha? An examination of theory and applications. Journal of Applied Psychology, 78(1), 98-104.

Davidson, J. C., \& Caddell, D. P. (1994) Religion and the meaning of work, Journal for the Scientific Study of Religion, 33(2), 135-147.

Dawis, R. V. (1991). Vocational interests, values, and preferences. In M. D. Dunnette \& L. M. Hough (Eds.), Handbook of Industrial and Organizational Psychology (pp. 833-871). Palo Alto, CA: Consulting Psychologists Press.

Deci, E. L., \& Ryan, R. M. (2000). Self-determination theory and the facilitation of intrinsic motivation, social development, and well-being. American Psychologist, 55(1), 68-78.

Dekas, K. H., \& Kamin, M.(2008). Work orientation: A review and theoretical elaboration. Paper presented at the annual meeting of the Academy of Management, Anaheim, CA. 
Dekas, K. H., \& Tosti, J. (2008). Reinforcing and reorienting work orientation research: Beyond jobs, careers and callings. Paper presented at the annual meeting of the Academy of Management, Anaheim, CA

Delle Fave, A., \& Massimini, F. (2003). Optimal experience in work and leisure among teachers and physicians: Individual and bio-cultural implications. Leisure Studies, 22, 323-342.

Dik, B. J., \& Duffy, R. D. (2009). Calling and vocation at work: Definitions and prospects for research and practice. The Counseling Psychologist, 37, 424-450.

Dobrow, S. (2006). Having a Calling: A Longitudinal Study of Young Musicians, Unpublished doctoral dissertation, Harvard University.

Dubin, R. (1956). Industrial workers' worlds: A study of the "central life interests" of industrial workers. Social Problems, 3(3), 131-142.

Elangovan, A. R., Pinder, C. C., \& McLean, M. (2010). Callings and organizational behavior. Journal of Vocational Behavior, 76(3), 428-440.

Elliot, A. J., \& Harackiewicz, J. M. (1996). Approach and avoidance achievement goals and intrinsic motivation: A meditational analysis. Journal of Personality and Social Psychology, 70, 416-475.

England, E. W. (1967). Personal values systems of American managers. Academy of Management Journal, 10, 53-68.

Fagan, C. (2001). Time, money and the gender order: Work orientations and working-time preferences in Britain. Gender, Work and Organization, 8(3), 239-266.

George, J. M., \& Jones, G. R. (1996). The experience of work and turnover intensions: Interactive effects of value attainment, job satisfaction, and positive mood. Journal of Applied Psychology, 81(3), 318-325.

Grant, M. (1960). The World of Rome. London: Weidenfeld and Nicholson.

Hakim, C. (1991). Grateful slaves and self-made women: Fact and fantasy in women's work orientations. European Sociological Review, 7(2), 101-121.

Hall, D.T., \& Chandler, D.E. (2005). Psychological success: When the career is a calling. Journal of Organizational Behavior, 26,155-176.

Holland, J. L. (1992). Making Vocational Choices: A Theory of Vocational Personalities and Work Environments ( ${ }^{\text {nd }}$ Ed.). Odessa, FL: Psychological Assessment Resources.

Hughes, E. C. (1958). Men and Their Work, Glencoe, IL: Free Press.

Johnstone, A., \& Johnston, L. (2005). The relationship between organizational climate, occupational type, and workaholism. New Zealand Journal of Psychology, 34(3), 181188.

Kanfer, R. M., \& Heggestad, E. D. (1997). Motivational traits and skills: A person-centered approach to work motivation. In B. Staw and L.L. Cummings (Eds.). Research in Organizational Behavior (vol. 19), 1-56. Greenwich, CT: JAI Press.

Kirkman, B. L., \& Rosen, B. (1999). Beyond self-management: Antecedents and consequences of team empowerment, Academy of Management Journal, 42(1), 58-74.

Maslach, C. (1982). Burnout: The Cost of Caring. Englewood Cliffs, NJ: Prentice Hall.

Meglino, B., \& Korsgaard, M.A. (2006). Considering situational and dispositional approaches to rational self-interest: An extension and response to De Dreu. Journal of Applied Psychology, 92(6), 1253-1259.

Mottaz, C. J. (1985). The relative importance of intrinsic and extrinsic rewards as determinants of work satisfaction. Sociological Quarterly, 26, 365-385. 
Oates, K. L. M., Hall, E. L., \& Anderson, T. L. (2005). Calling and conflict: A qualitative exploration of interrole conflict and the sanctification of work in Christian mothers in academia. Journal of Psychology and Theology, 33(3), 210-233.

Ravlin, E. C., \& Meglino, B. M. (1987). Effect of values on perception and decision making: A study of alternative work values measures. Journal of Applied Psychology, 72, 666-673.

Roberson, L. (1990). Functions of work meanings in organizations: Work meaning and work motivation. In Brief, A.P. \& Nord, W.R. (Eds.) Meanings of Occupational Work: A Collection of Essays. (pp. 107-134). Lexington, MA: Lexington Books.

Robinson, J. P., Shaver, P. R., \& Wrightman, L. S. (1991). Criteria for Scale Selection and Evaluation in Measure of Personality and Social Psychology Attitudes. San Diego, CA: Academic Press.

Rynes, S. L., \& Connerley, M. L. (1993). Applicant reactions to alternative selection procedures. Journal of Business and Psychology, 7, 261-277.

Schwartz, S. H. (1994). Are there universal aspects in the structure and contents of human values? Journal of Social Issues, 50(4), 19-45.

Siebert, S. E., Crant, J. M., \& Kraimer, M.L. (2001). What do proactive people do? A longitudinal model linking proactive personality and career success. Personnel Psychology, 54(4), 845-874.

Spence, J. T., \& Helmreich, R. L. (1983). Achievement-related motives and behaviors. In J.T. Spence (Ed.), Achievement and Achievement Motives, 7-74. San Francisco, CA: Freeman.

Steger, M. F., Frazier, P., Oishi, S., \& Kaler, M. (2006). The meaning of life questionnaire: Assessing the presence of and search for meaning in life. Journal of Counseling Psychology, 55(1), 80-93.

Super, D. E. (1980). A life-span, life-space approach to career development. Journal of Vocational Behavior, 16, 282-298.

Tosti, J. (2008). Reevaluating job, career and calling: The influential role of occupations. Paper presented at the annual meeting of the Academy of Management, Anaheim, CA

Vansteenkiste, M., Neyrinck, B., Niemiec, C. P., Soenens, B., De Witte, H., \& Van den Broeck, A. (2007). On the relations among work value orientations, psychological need satisfaction and job outcomes: A self-determination theory approach. Journal of Occupational and Organizational Psychology, 80, 251-277.

Vroom, V. H. (1964). Work and Motivation. New York: Wiley.

Weber, M. (1958). The Protestant Ethic and the Spirit of Capitalism. New York: Scribner.

Weiss, J. W., Skelley, M. F., Hall, D. T., \& Haughey, J. C. (2003). Calling, new careers and spirituality: A reflective perspective for organizational leaders and professionals in $\mathrm{M}$. Pava (Ed.) Research in Ethical Issues in Organizations, 175- 201.

Wrzesniewski, A. E. (1999). Jobs, Careers, and Callings: Work Orientation and Job Transitions. Unpublished doctoral dissertation, University of Michigan.

Wrzesniewski, A. (2003). Finding positive meaning in work. In K. S. Cameron, J. E. Dutton, \& R. E. Quinn (Eds.), Positive Organizational Scholarship. San Francisco: Berrett-Koehler.

Wrzesniewski, A. E., \& Dutton, J. E. (2001). Crafting a job: Revisioning employees as active crafters of their work, Academy of Management Review, 26(2), 179-201.

Wrzesniewski, A. E., Dutton, J. E., \& Debebe, G. (2003). Interpersonal sensemaking and the meaning of work, Research in Organizational Behavior, 25, 93-135.

Wrzesniewski, A. E., McCauley, C., Rozin, P., \& Schwartz, B. (1997). Jobs, careers, and callings: People's relations to their work, Journal of Research in Personality, 31, 21-33. 
Yugo, J. E. (2006). The Effect of Response Format on the Criterion Related Validity of a Measure of Work Orientation. Unpublished master's thesis, Bowling Green State University, Bowling Green, $\mathrm{OH}$. 